\title{
Physiological indices and phytomass partition in precocious dwarf cashew clones irrigated with saline waters
}

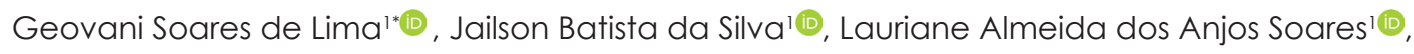

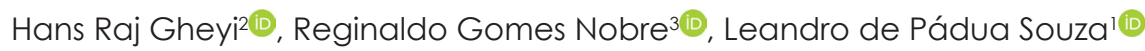 \\ 'Federal University of Campina Grande, Pombal, Brazil \\ ${ }^{2}$ Federal University of Recôncavo da Bahia, Cruz das Almas, Brazil \\ ${ }^{3}$ Federal Rural University of the Semi-arid, Caraúbas, Brazil \\ *Corresponding author, e-mail: geovani.soares@pq.cnpq.br
}

\begin{abstract}
This research aimed to evaluate the physiological indices and the accumulation of phytomass in clones of precocious dwarf cashew under salt stress during rootstock formation. The experiment was conducted in greenhouse in the municipality of Pombal-PB. The experimental design was in randomized blocks, and the treatments were organized in a $5 \times 3$ factorial arrangement, constituting the levels of electrical conductivity of the irrigation water-ECW $\left(0.4\right.$-Control; $1.2 ; 2.0 ; 2.8$, and $\left.3.6 \mathrm{dS} \mathrm{m}^{-1}\right)$ and the clones of precocious dwarf cashew (Faga 11, Embrapa 51, CCP 76), with three replications and two plants per plot. Water salinity higher than 0.4 $\mathrm{dS} \mathrm{m}^{-1}$ resulted in a decrease of the relative growth in plant height, leaf area, and phytomass accumulation in the cashew plant. The cashew clones are sensitive to water salinity from $0.4 \mathrm{dS} \mathrm{m}^{-1}$. Among the physiological indicators, the leaf area ratio, the sclerophylly index, and the root/shoot ratio of the precocious dwarf cashew are highlighted as salt stress indicators. The use of water with $0.4 \mathrm{dS} \mathrm{m}^{-1}$ of electrical conductivity is recommended for the formation of cashew rootstocks.
\end{abstract}

Keywords: Anacardium Occidentale L., salt stress, tolerance

\section{Introduction}

Cashew (Anacardium occidentale L.) is a widely cultivated species in the Northeast region of Brazil, standing out in the socioeconomic context due to the nutritive and commercial value of its fruits, consumed both in natura and after industrialization, and figuring as an important crop in job and income generation (Araújo et al., 2014). The cashew fruit presents high nutritive value in the form of vitamins, tannins, mineral salts, and organic acids, also presenting calcium, iron, and phosphorus, among others (Lima et al., 2007).

In spite of the importance of cashew farming in the semiarid region of the Brazilian Northeast, the qualitative and quantitative scarcity of water resources becomes a limiting factor for the establishment of this fruit species. Consequently, the use of saline waters represents a constant challenge for agricultural crops and has been considered a severe restriction on agricultural productivity (Nadeem et al., 2019). Salinity can inhibit plant growth due to the water stress caused by the reduction of the osmotic potential of the soil solution, ionic toxicity and unbalance in the absorption of mineral nutrients, and oxidative stress due to the generation of reactive oxygen species (ROSField capacity) (Isayenkov \& Maathuis, 2019).

The deleterious effects of salinity affect different physiological and metabolic processes of the plants, with the responses to these changes being frequently accompanied by a variety of symptoms, such as the decrease in the leaf area, increase in thickness and leaf succulence, leaf abscission, and root necrosis (Rahneshan et al., 2018). In this context, the growth rate and the production of phytomass are highlighted as essential criteria for the determination of the tolerance of the crops to salt stress (Sá et al., 2016).

Plant tolerance to salt stress depends on the species, clone, phenological stage, intensity and duration of the stress, edaphoclimatic conditions, and irrigation management (Reis et al., 2016; Mesquita et al., 2019). The distinctions between species are associated to the establishment of physiological and biochemical mechanisms, such as osmotic adjustment, changes in photosynthetic pathways, synthesis of compatible osmolytes, and activation of enzymatic and non-enzymatic antioxidant systems, which increase the tolerance of the plants cultivated under high salt 
concentrations (Freitas et al., 2014).

Considering the adverse effects of salt stress on the growth and production of the crops, and taking genetic variability into account, the identification of tolerant species has received attention in the last decades, standing out as an important strategy for the development of sustainable agriculture in the semiarid region of the Brazilian Northeast. In this perspective, this research aimed to evaluate precocious dwarf cashew clones cultivated under irrigation with saline waters during the formation of rootstocks.

\section{Material and Methods}

The research was conducted in greenhouse (6 $6^{\circ} 48^{\prime} 16^{\prime}$ 'latitude $S, 37^{\circ} 49^{\prime} 15^{\prime \prime}$ longitude $W$ and average elevation of $175 \mathrm{~m}$ ), belonging to the Center for Sciences and Agri-Food Technology-CCTA, municipality of Pombal, Paraíba state, Brazil.

The treatments resulted from the combination of five levels of electrical conductivity of the irrigation water

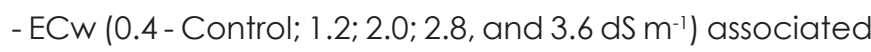
with three precocious dwarf cashew clones (Faga 11, Embrapa 51, CCP 76), in a $5 \times 3$ factorial scheme. The experimental design was in randomized blocks, with two plants per plot and three replications.

The substrate was prepared as a mixture of Regolithic Neosol (Entisol) of sandy-loam texture, sand, and organic matter (using well- decomposed manure as a source) from the rural zone of the municipality of São Domingos, PB, in a 2:1:1 proportion based on mass, respectively. The chemical and physical characteristics were obtained according to the methodology contained in Donagema et al. (2011): $\mathrm{Ca}^{2+}=2.42 \mathrm{cmol}_{\mathrm{C}} \mathrm{kg}^{-1} ; \mathrm{Mg}^{2+}$ $=5.84 \mathrm{cmol}_{\mathrm{c}} \mathrm{kg}^{-1} ; \mathrm{Na}^{+}=0.09 \mathrm{cmol}_{\mathrm{c}} \mathrm{kg}^{-1} ; \mathrm{K}^{+}=0.21 \mathrm{cmol}_{\mathrm{c}}$ $\mathrm{kg}^{-1} ; \mathrm{H}^{+}+\mathrm{Al}^{3+}=0.00 \mathrm{cmol}_{\mathrm{C}} \mathrm{kg}^{-1} ; \mathrm{SB}=\mathrm{CTC}=8.56 \mathrm{cmol}_{\mathrm{c}}$ $\mathrm{kg}^{-1}$; organic matter $=3.80 \mathrm{dag} \mathrm{kg}^{-1} ; \mathrm{P}=11.99 \mathrm{mg} \mathrm{kg}^{-1}$; $\mathrm{pH}$ in water $(1: 2.5)=7.00$; electrical conductivity of the saturation extract $=0.20 \mathrm{dS} \mathrm{m^{-1 }}$; sand $=846.3 \mathrm{~g} \mathrm{~kg}^{-1}$; silt $=137.0 \mathrm{~g} \mathrm{~kg}^{-1}$; clay $=16.3 \mathrm{~g} \mathrm{~kg}^{-1}$; moisture at $33.42 \mathrm{kPa}$ (field capacity) $=11.16 \mathrm{dag} \mathrm{kg}^{-1}$; moisture at $1519.5 \mathrm{kPa}$ (wilting point) $=4.23 \mathrm{dag} \mathrm{kg}^{-1}$.

The irrigation waters of the respective treatments were prepared by dissolving $\mathrm{NaCl}$ in tap water $(\mathrm{ECW}=$ $0.30 \mathrm{dS} \mathrm{m}^{-1}$ ), based on the ratio between the ECW and the concentration of salts $\left(10 \mathrm{mmol}_{\mathrm{c}} \mathrm{L}^{-1}=1 \mathrm{dS} \mathrm{m}^{-1}\right)$, extracted from Richards (1954). After the preparation and calibration of the ECW using a handheld conductivity meter, the waters were stored in plastic container with capacity for $200 \mathrm{~L}$, being properly protected in order to avoid evaporation.
Before sowing, the moisture content of the substrate was increased until reaching field capacity, using the respective water from each treatment. After sowing, the irrigation was performed daily by applying, in each container, a water volume as to maintain the moisture of the substrate close to field capacity, with the applied volume being determined according to the water requirements of the plants, estimated by water balance: applied volume minus the drained volume from the previous irrigation, added by a leaching fraction of 0.10. The leaching fraction was based on the textural class of the soil and the tolerance of the crop to salinity, and its purpose was to minimize the accumulation of salts in the root zone. For the collection of the drained water volume, a plastic bag was inserted in each container in order to direct the drainage water to a plastic bottle and later determine the water intake by the plants.

In this study, seeds from the following precocious dwarf cashew clones were used: Faga 11, Embrapa 51, and CCP 76, whose sowing was performed at the depth of $3 \mathrm{~cm}$, placing one seed per container in the vertical position, that is, with the thinner extremity downside and the peduncle insertion scar upwards.

The fertilization with phosphorus and nitrogen was performed according to the recommendation by Novais et al. (1991), applying the equivalent to $300 \mathrm{mg}$ of $\mathrm{P}_{2} \mathrm{O}_{5} \mathrm{~kg}^{-1}$ of soil and $100 \mathrm{mg}$ of $\mathrm{N} \mathrm{kg}^{-1}$ of soil, respectively. Monoammonium phosphate was used as a phosphorus source, and the $\mathrm{N}$ source was complemented with urea. Phosphorus and nitrogen were applied weekly. The micronutrient needs of the cashew plant were supplied through biweekly applications of a ubyfol solution [ $(\mathrm{N}$ (15\%); $\mathrm{P}_{2} \mathrm{O}_{5}$ (15\%); $\mathrm{K}_{2} \mathrm{O}$ (15\%); Ca (1\%); Mg (1.4\%); S (2.7\%); Zn (0.5\%); B (0.05\%); Fe (0.5\%); Mn (0.05\%); Cu (0.5\%); Mo $(0.02 \%)$ ] containing $1.0 \mathrm{~g} \mathrm{~L}^{-1}$. The sprayings were performed on the adaxial and abaxial surfaces of the leaves, at the end of the afternoon 5:00 p.m.

The evaluations were performed at 25 and 75 days after sowing (DAS). At 25 and 75 DAS, the following variables were evaluated: plant height $(\mathrm{PH})$, stem diameter (SD), and leaf area (LA). From these data, relative growth rates of stem diameter $\left(R G R_{S D}\right)$, plant height $\left(R G R_{P H}\right)$, and leaf area $\left(R G R_{L A}\right)$ were calculated according to Benincasa (2003). The following data were measured only at 75 DAS: leaf dry phytomass (LDP), stem dry phytomass (StDP), root dry phytomass (RDP), and dry phytomass of aerial part (DPAP), leaf area ratio (LAR), root/shoot ratio (R/SR), sclerophylly index (SI).

The RGR for the stem diameter $\left(R G R_{S D}\right)$, plant height $\left(R G R_{P H}\right)$, and leaf area $\left(R G R_{L A}\right)$ of the cashew was 
calculated according to Benincasa (2003) through Eq. 1.

$$
\mathrm{RGR}=\frac{(\operatorname{InX} 2-\operatorname{InX} 1)}{(\mathrm{t} 2-\mathrm{t} 1)}
$$

In which: $R G R$ = Relative growth rate in stem diameter $\left(\mathrm{mm} \mathrm{mm}^{-1} \mathrm{~d}^{-1}\right)$, plant height $\left(\mathrm{cm} \mathrm{cm}^{-1} \mathrm{~d}^{-1}\right)$, and leaf area $\left(\mathrm{cm}^{2} \mathrm{~cm}^{-2} \mathrm{~d}^{-1}\right)$;

$\mathrm{X}_{1}=\mathrm{SD}_{1}, \mathrm{PH}_{1}, \mathrm{LA}_{1}=$ Stem diameter $(\mathrm{mm})$, plant height $(\mathrm{cm})$ and leaf area $\left(\mathrm{cm}^{2}\right)$ at time $t_{1} ; X_{2}=\mathrm{SD}_{2^{\prime}}, \mathrm{PH}_{2^{\prime}} \mathrm{LA}_{2}$ $=$ Stem diameter $(\mathrm{mm})$, plant height $(\mathrm{cm})$ and leaf area $\left(\mathrm{cm}^{2}\right)$ at time $\mathrm{t}_{2}$, and $\mathrm{In}=$ natural logarithm.

The stalk of each plant was cut close to the ground for the determination of the dry phytomass of stem, leaves, and roots, being later placed to dry in a forced air oven at $65^{\circ} \mathrm{C}$. The leaf area ratio (LAR) and the root/shoot ratio (R/RS) were determined according to Benincasa (2003). The sclerophyll index - SI (g dry phytomass - DP $\mathrm{cm}^{-2}$ ) of the cashew was determined according to the ratio proposed by Costa et al. (2003), obtained through: [(dry phytomass of leaves) /leaf area].
The data were checked as to the homogeneity of variances and later subjected to analysis of variance by the F test at the levels 0.05 and 0.01 probability. The analysis of polynomial regression was performed for the water salinity levels and a means comparison test (Tukey) was performed for the clones. When the interaction between factors ( $\mathrm{SL} \times \mathrm{CL}$ ) was significant, the unfolding of the salt levels within each clone was performed using the statistical software SISVAR (Ferreira, 2014).

\section{Results and Discussion}

There was a significant effect of the water salt levels on the relative growth rate in plant height $\left(R G R_{P H}\right)$ and leaf area $\left(R_{G} R_{L A}\right)$ in the period from 25 to 75 days after sowing and for the leaf area ratio (LAR) and root/ shoot ratio (R/SR) of precocious dwarf cashew clones at 75 DAS (Table 1). There was a significant difference between clones only for the R/SR. There was no significant interaction between the SL $\times$ CL factors.

Table 1. Summary of the analysis of variance of the relative growth rate in stem diameter $\left(R G R_{S D}\right)$, plant height $\left(R G R_{P H}\right)$, and leaf area $\left(R G R_{L A}\right)$ in the period from 25 to 75 days after sowing (DAS), leaf area ratio (LAR), root/shoot ratio (R/SR), and sclerophyll index (SI) of clones of precocious dwarf cashew irrigated with saline waters, at 75 DAS.

\begin{tabular}{|c|c|c|c|c|c|c|}
\hline \multirow{4}{*}{ Source of variation } & \multicolumn{6}{|c|}{ Mean squares } \\
\hline & $R_{G} R_{S D}$ & $\mathrm{RGR}_{\mathrm{PH}}$ & $R_{G} R_{L A}$ & LAR & $R / S R$ & $\mathrm{SI}$ \\
\hline & \multicolumn{3}{|c|}{$25-75$} & \multicolumn{3}{|c|}{75} \\
\hline & \multicolumn{6}{|c|}{ Days after sowing } \\
\hline Saline levels (SL) & $0.000004^{\text {ns }}$ & $0.000016^{* *}$ & $0.000032^{* *}$ & $2102.86^{* *}$ & $0.0348^{* *}$ & $0.000014^{* *}$ \\
\hline Linear regression & $0.000015^{\mathrm{ns}}$ & $0.000054^{* *}$ & $0.00011^{* *}$ & $7406.18^{* *}$ & $0.1364^{* *}$ & $0.000056^{* *}$ \\
\hline Quadratic regression & $0.000001^{\text {ns }}$ & $0.000003^{\text {ns }}$ & $0.000006^{\mathrm{ns}}$ & $596.54^{\mathrm{ns}}$ & $0.0003^{\text {ns }}$ & $0.000001^{\mathrm{ns}}$ \\
\hline Clones (CL) & $0.000005^{\mathrm{ns}}$ & $0.000002^{\text {ns }}$ & $0.000009^{n s}$ & $143.80^{\text {ns }}$ & $0.0118^{*}$ & $0.000001^{\mathrm{ns}}$ \\
\hline Interaction (SL x CL) & $0.000002^{\text {ns }}$ & $0.000008^{\text {ns }}$ & $0.000003^{\text {ns }}$ & $146.26^{\mathrm{ns}}$ & $0.0018^{\text {ns }}$ & $0.000004^{\mathrm{ns}}$ \\
\hline Blocks & $0.000002^{\text {ns }}$ & $0.000002^{\mathrm{ns}}$ & $0.000001^{\mathrm{ns}}$ & $176.64^{\mathrm{ns}}$ & $0.00007^{\mathrm{ns}}$ & $0.000004^{\mathrm{ns}}$ \\
\hline Residual & $0.000001^{\text {ns }}$ & 0.000001 & 0.000003 & 131.80 & 0.0017 & 0.000001 \\
\hline$\overline{C \vee}(\%)$ & 15.25 & 15.66 & 11.12 & 12.47 & 12.17 & 15.45 \\
\hline
\end{tabular}

The increase in water salinity allowed a decrease in the relative growth rate in plant height of $21.15 \%$ per unitary increment in the ECW. It may be noted through the regression equation (Figure $1 \mathrm{~A}$ ) that the plants presented a reduction in the $R_{\mathrm{P}} \mathrm{R}_{\mathrm{PH}}$ of $0.00352 \mathrm{~cm} \mathrm{~cm}^{-1}$ $\mathrm{d}^{-1}$ when cultivated with water with ECW of $3.6 \mathrm{dS} \mathrm{m}^{-1}$, compared to those under irrigation with ECW of $0.4 \mathrm{dS}$ $\mathrm{m}^{-1}$. The relative growth reflects the efficiency of the use of plant reserves since it represents the capacity of the plant in producing new material, as a function of the already existing material (Bezerra et al., 2016). Growth inhibition under salinity conditions occurs due to the decrease in the availability of water to the plants, as a function of the osmotic effect, hardening the absorption of water and nutrients by the plants, which requires greater energy consumption by the plants to maintain metabolic activities; consequently, it acts negatively on the physiological processes, decreasing meristematic activity and cell elongation, a fact that retards or inhibit plant growth (Sousa et al., 2011). These results corroborate those obtained by Torres et al. (2014), when evaluating the growth of seedlings of the 'CCP 76' precocious dwarf cashew irrigated with waters with salinity varying from 0.5 to $12.5 \mathrm{dS} \mathrm{m} \mathrm{m}^{-1}$, verifying a reduction in the $\mathrm{RGR}_{\mathrm{PH}}$ in the period from 10 to 70 days after sowing.

The relative growth in the leaf area of the precocious dwarf cashew was reduced by the irrigation with saline waters. Through the regression equation (Figure $1 \mathrm{~B}$ ) it is observed that the highest $\mathrm{RGR}_{\mathrm{LA}}(0.0055$ $\mathrm{cm}^{2} \mathrm{~cm}^{-2} \mathrm{~d}^{-1}$ ) was obtained when the plants were cultivated under the lowest level of ECW $\left(0.4 \mathrm{dS} \mathrm{m}^{-1}\right)$. On the other hand, the use of water with a salinity of $3.6 \mathrm{dS}$ $\mathrm{m}^{-1}$ provided the lowest $\operatorname{RGR}_{\mathrm{LA}}\left(0.00134 \mathrm{~cm}^{2} \mathrm{~cm}^{-2} \mathrm{~d}^{-1}\right)$ in the plants. When comparing the $\mathrm{RGR}_{\mathrm{LA}}$ values in the plants 
under ECW of $3.6 \mathrm{dS} \mathrm{m}^{-1}$ with those that received $0.4 \mathrm{dS}$ $\mathrm{m}^{-1}$, a reduction $0.00416 \mathrm{~cm}^{2} \mathrm{~cm}^{-2} \mathrm{~d}^{-1}$ can be verified. The reduction in the growth of the leaf area represents a tolerance mechanism of the plants to salt stress, as a measure to reduce water loss through transpiration and to maintain the low absorption of toxic ions, mainly $\mathrm{Na}^{+}$ and $\mathrm{Cl}^{-}$(Gomes et al., 2011). However, the reduction in

the leaf area represents a decrease in the capture of luminous energy as well as in the fixation of $\mathrm{CO}_{2}$ per area unit and, with less transpiration, the plant will absorb less water and nutrients and perform less $\mathrm{CO}_{2}$ exchange with the environment, reducing its photosynthetic potential and, consequently, its growth (Santos et al., 2012).

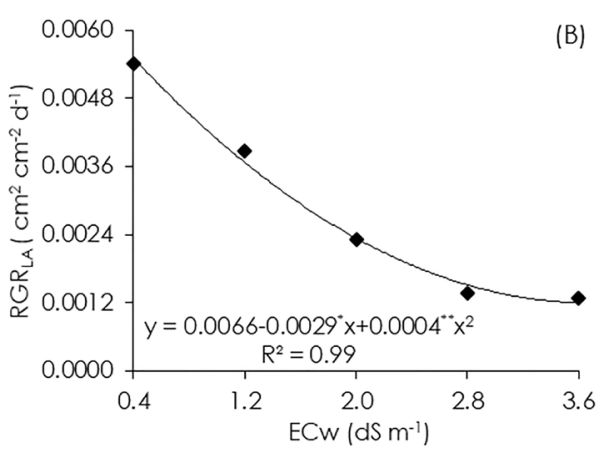

(B)

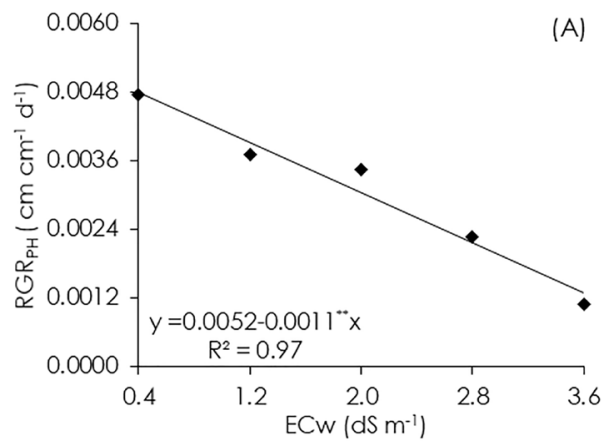

Figure 1. Relative growth rate in plant height - $R G R_{P H}(A)$ and leaf area - $R G R_{L A}(B)$ of precocious dwarf cashew clones as a function of the irrigation with saline waters - ECW, in the period from 25 to 75 days after sowing (DAS).

The leaf area ratio is a morphophysiological component of growth that expresses the ratio between the leaf area and the total dry phytomass, and represents the assimilatory surface for photosynthesis (Silva et al., 2007). In this manner, it is verified that the salinity of the irrigation water provided an increase in the leaf area of the cashew plants, at 75 DAS (Figure 2A), also verifying increases of $16.34 \%$ per unitary increment, that is, the plants cultivated under ECW of $3.6 \mathrm{dS} \mathrm{m}^{-1}$ presented

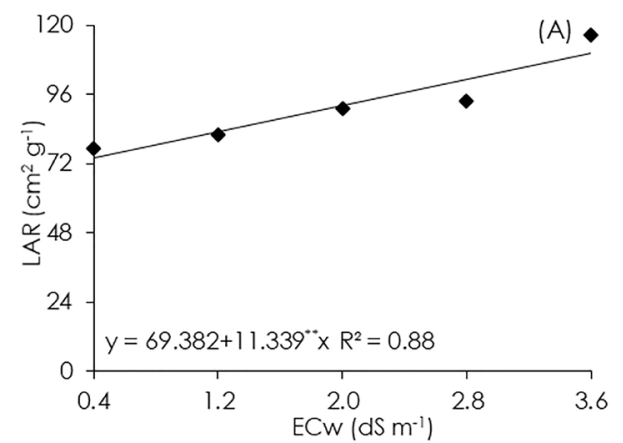

an increase in the RAF of $36.284 \mathrm{~cm}^{2} \mathrm{~g}^{-1}$ compared to those under the lowest salt level $\left(0.4 \mathrm{dS} \mathrm{m}^{-1}\right)$. Such a fact evidences the lower photosynthetic efficiency per unit of leaf area of the plants cultivated under high salt levels. On the contrary, the data obtained in this study, Bezerra et al. (2017) observed a reduction in the LAR with the increment of the ECW $\left(0.5\right.$ to $\left.5.5 \mathrm{dS} \mathrm{m}^{-1}\right)$, verifying a decrease in this variable in both times of study (25 and 40 DAS).

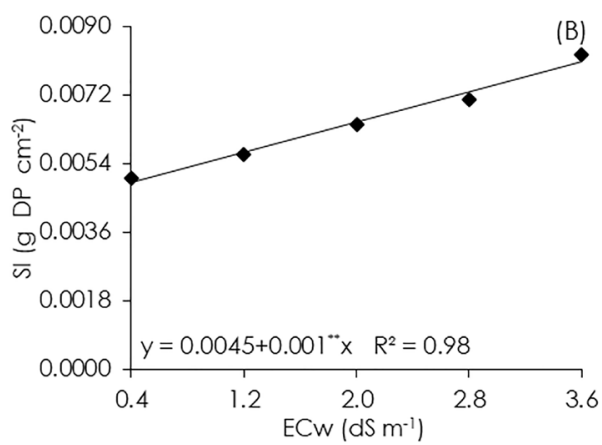

Figure 2. Leaf area index - LAR (A) and sclerophyll index - SI (B) of the precocious dwarf cashew, as a function of the irrigation with saline waters - ECW at 75 days after sowing.
The sclerophyll index is an indicator of the thickening of the walls of the mesophyll cells and represents the amount of dry matter per area unit, being one of the most easily seen modifications in glycophyte species cultivated under salt stress conditions (Costa et al., 2003). It is verified (Figure 2B) that there was an increment in the SI of $22.22 \%$ per unitary increment of the $\mathrm{ECW}$, that is, the cashew plants, when irrigated with water with salinity of $3.6 \mathrm{dS} \mathrm{m}^{-1}$ presented an increase in the SI of
$0.0032 \mathrm{~g} \mathrm{DP}^{-2}$ (65.30\%) compared to those subjected to the treatment with the lowest salt level $\left(0.4 \mathrm{dS} \mathrm{m}^{-1}\right)$, indicating a possible acclimative response of these clones to salt stress. Costa et al. (2003), when studying the effects of salinity in the growth and contents of organic and inorganic solutes in cultivars of Vigna unguiculata, observed that the salt stress significantly increased the sclerophyll index in the cultivars Epace 10, Pitiúba, and vita 5. 
The root/shoot ratio of the cashew plant increased linearly with the use of saline waters (Figure 3A), increasing $20.07 \%$ per unitary increment of the ECW. When comparing the R/SR of the cashew seedlings cultivated with water salinity of $3.6 \mathrm{dS} \mathrm{m}^{-1}$, an increment of $59.46 \%$ $\left(0.155 \mathrm{~g} \mathrm{~g}^{-1}\right)$ is observed in relation to those subjected to

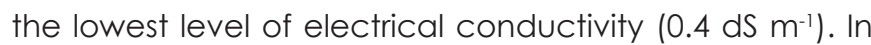
this manner, it is evidenced that the growth of the shoot part of the cashew plants was more damaged by the salt stress in relation to the root system, providing higher $R / S R$. The higher R/SR can be considered an adaptative characteristic of the plants subjected to environments with salt stress. Such a fact results in greater absorption of water and nutrients by the plants and, also, it decreases the losses through transpiration, since the allocation of mass to the leaves is decreased (Suassuna et al., 2012). In a research with precocious dwarf cashew clones (CCP 06, ССР 09, ССР 1001, Embrapa 50, and Embrapa 51), Carneiro et al. (2002), verified that the irrigation with saline waters (ECW: 0.7 to $2.8 \mathrm{dS} \mathrm{m}^{-1}$ ) resulted in the increase of the $R / S R$ of the plants at 50 days after sowing.
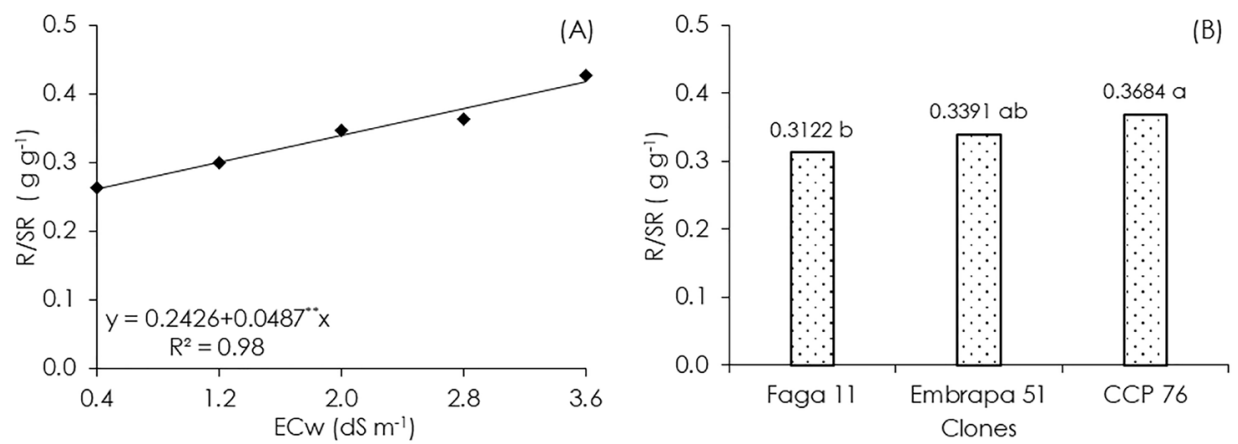

Figure 3. Root/shoot ratio - R/SR of the precocious dwarf cashew as a function of the irrigation with saline waters - ECW (A) and the clones (B) at 75 days after sowing. Means with different letters indicate that the treatments are statistically different by Tukey's test at $\mathrm{p}<0.05$.

Regarding effect of the clones (Figure 3B), it is verified that the CCP 76 only statistically differed from the Faga 11 clone. Conversely, there was no significant difference between the clones Faga 11 and Embrapa 51 and Embrapa 51 and CCP 76. In absolute terms, it is verified, among the studied clones, that the highest and lowest R/SR were obtained in the CCP $76(0.3684$ $\mathrm{g} \mathrm{g}^{-1}$ ) and Faga 11 (0.3122 $\mathrm{g} \mathrm{g}^{-1}$ ), respectively. The R/ $S R$ is an important characteristic in the identification of tolerant clones to salt stress, standing out as an indicative of morphophysiological adaptation, since with the reduction in the water potential of the soil, due to the osmotic component, the plants increase the water absorption capacity and decrease the transpiration rate, aiming at the maintenance of cell turgidity (Gurgel et al., 2007). Differently from the results obtained in this study, Carneiro et al. (2002) verified that the use of waters with

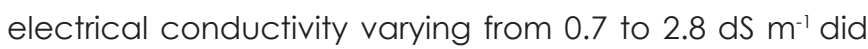
not influence the R/SR of the CCP 06, CCP 09, CCP 1001, Embrapa 50, and Embrapa 51 clones at 70 DAS.

Through the analysis of variance (Table 2) it is verified that the salt levels of the irrigation water influenced the dry phytomass of leaves (LDP), stem (StDP), roots (RDP), and dry phytomass of aerial part (DPAP) of the cashew clones. There was no effect of the clones and the interaction between factors ( $S L \times C L$ ) over none of the evaluated variables at 75 DAS.

Table 2. Summary of the analysis of variance for the accumulation of leaf dry phytomass (LDP), stem dry phytomass (StDP), root dry phytomass (RDP), and dry phytomass of aerial part (DPAP) of clones of precocious dwarf cashew irrigated with saline waters, at 75 days after sowing (DAS).

\begin{tabular}{lcccc}
\hline \multirow{2}{*}{ Source of variation } & \multicolumn{4}{c}{ Mean squares } \\
\cline { 2 - 5 } & LDP & StDP & RDP & DPAP \\
\hline Saline levels (SL) & $2.03^{* *}$ & $5.32^{* *}$ & $0.77^{* *}$ & $10.41^{* *}$ \\
Linear regression & $7.84^{* *}$ & $17.44^{* *}$ & $2.42^{* *}$ & $39.97^{* *}$ \\
Quadratic regression & $0.12^{\text {ns }}$ & $3.15^{*}$ & $0.41^{*}$ & $0.74^{\text {ns }}$ \\
Clones (CL) & $0.27^{\text {ns }}$ & $0.85^{\text {ns }}$ & $0.003^{\text {ns }}$ & $2.03^{\text {ns }}$ \\
Interaction (SL x CL) & $0.40^{\text {ns }}$ & $0.33^{\text {ns }}$ & $0.13^{\text {ns }}$ & $0.76^{\text {ns }}$ \\
Blocks & $0.32^{\text {ns }}$ & $0.26^{\text {ns }}$ & $0.13^{\text {ns }}$ & $0.40^{\text {ns }}$ \\
Residual & 0.20 & 0.25 & 0.56 & 0.92 \\
\hline CV (\%) & 20.86 & 14.83 & 23.42 & 26.94 \\
ns, ${ }^{* *},{ }^{*}$ respectively non-significant, significant at $p<0.01$ and $p<0.05$. & &
\end{tabular}


The salinity of the irrigation water inhibited the formation of phytomass in the leaves of the precocious dwarf cashew plant at 75 DAS (Figure 4A) verifying a reduction of $12.64 \%$ per unitary increment of the ECW. Comparatively, it can be noted that the plants, when

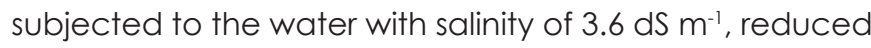
the LDP in $42.61 \%$ ( $\left.1.181 \mathrm{~g} \mathrm{plant}^{-1}\right)$ compared to the plants under ECW of $0.4 \mathrm{dS} \mathrm{m}^{-1}$. The reduction in the accumulation of dry phytomass in the leaves is in consonance with the decline observed in the relative growth rate in leaf area (Figure 1B), and may be related to the decrease in the photosynthetic rate of the plants and the shift in
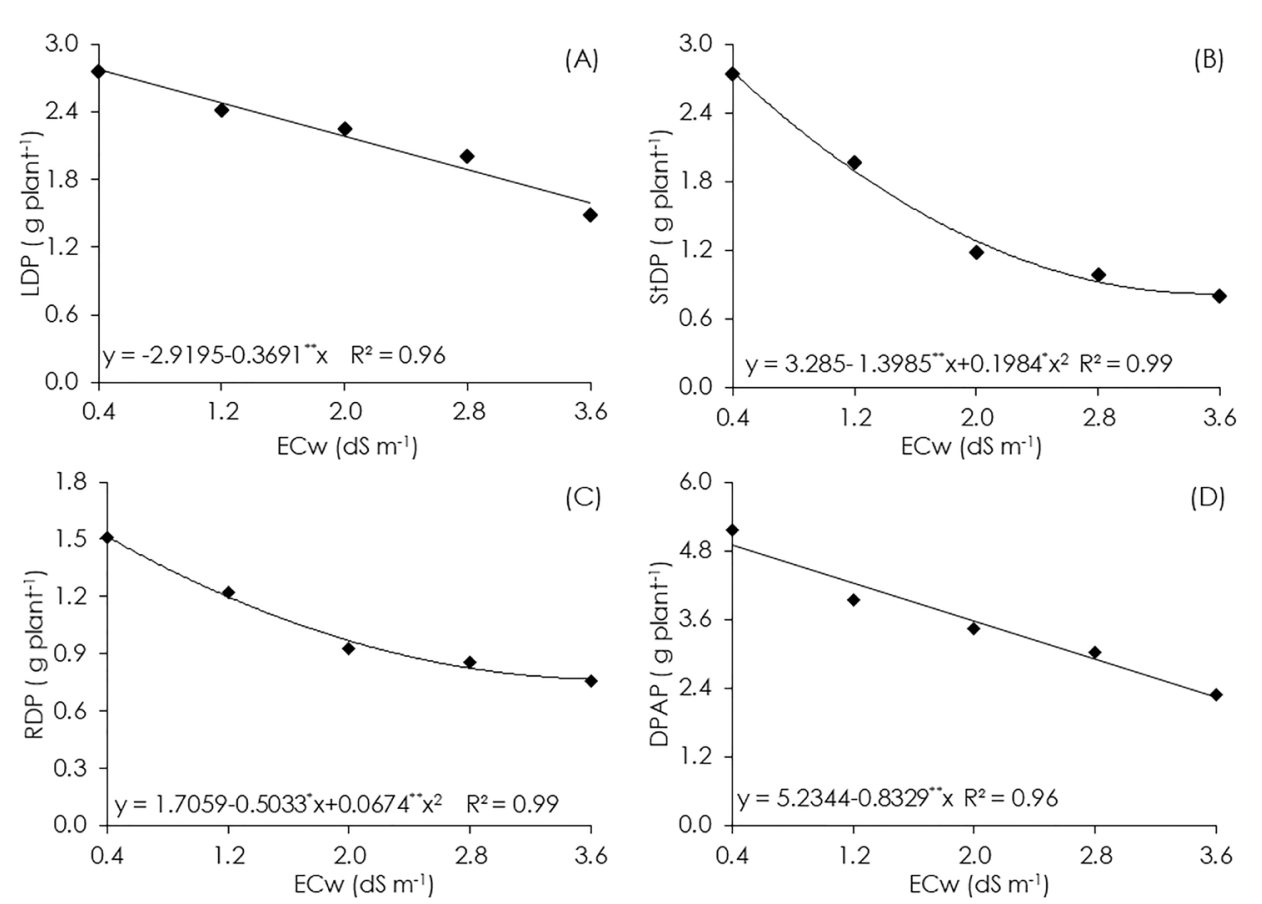

Figure 4. Dry phytomass of leaf - LDP (A), stem - StDP (B), roots - RDP (C), and dry phytomass of aerial part - DPAP (D) of precocious dwarf cashew clones as a function of the irrigation with saline waters - ECW at 75 days after sowing.

The distinct salt levels of the water provided a decrease in the dry phytomass of the stem (Figure 4B) of the precocious dwarf cashew plants at 75 days after sowing, whose maximum estimated value for the StDP (2.75 $\mathrm{g} \mathrm{plant}^{-1}$ ) was obtained when the plants were irrigated with the water with lowest salinity $\left(0.4 \mathrm{dS} \mathrm{m}^{-1}\right)$, decreasing from this level and reaching the minimum of $0.823 \mathrm{~g} \mathrm{plant}^{-1}$ in the plants cultivated under ECW of 3.6 $\mathrm{dS} \mathrm{m}^{-1}$. It is also verified from the regression equation that the plants under irrigation with ECW of $3.6 \mathrm{dS} \mathrm{m}^{-1}$ obtained a decline of $1.934 \mathrm{~g} \mathrm{plant}^{-1}$ in relation to those cultivated with the lowest salinity water $\left(0.4 \mathrm{dS}^{-1}\right)$.

The decline in phytomass accumulation is a consequence of the mechanisms of adjustment to salt stress conditions, as previously highlighted by Silva et al. (2011) and Silva Júnior et al. ( 2012), reflecting as one of the limitations for the reduction in phytomass

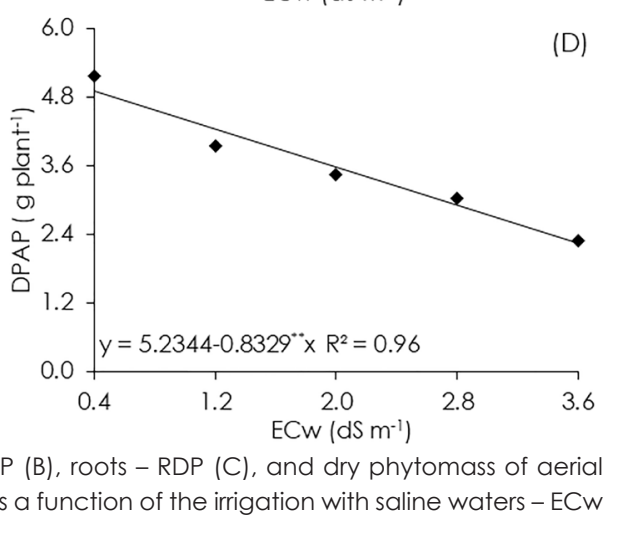

the energy destined to growth for the activation and maintenance of the integrity of membranes, synthesis of organic solutes for osmoregulation and/or protection of macromolecules, and regulation of the transport and ionic distribution in several organs within the cells (Silva et al., 2011; Silva Júnior et al., 2012). Sousa et al. (2010), when evaluating the effect of the salinity of the irrigation water (ECW: 3, 6, 9, and $12 \mathrm{dS} \mathrm{m}^{-1}$ ) on the initial growth of BRS 275 cashew seedlings also verified that the LDP was negatively affected by the increase in the salt levels, whose reduction was $6.30 \%$ per unitary increment of the ECW.

accumulation by the plants, and associated to the decrease of the photosynthetic activity, since the stress caused by the excess of salts in the water and/or soil promotes alterations in osmotic and ionic homeostasis, a fact that can contribute to the decrease in the accumulation of photoassimilates and, consequently, to the reduced plant growth (Araújo et al., 2016). The reduction in the formation of dry phytomass of stem in the plants cultivated under irrigation with saline waters was also observed by Araújo et al. (2018), when studying guava.

The dry phytomass of roots in the cashew plants followed the same trend verified for the StDP (Figure 4C), that is, the increase in the water salinity levels resulted in a decline of the accumulation of RDP. It is verified that the highest accumulation of RDP (1.51 $\left.\mathrm{g} \mathrm{plant}^{-1}\right)$, as well as the lowest $\left(0.76 \mathrm{~g} \mathrm{plant}^{-1}\right)$, were obtained when the 
plants were cultivated with ECW of 0.4 and $3.6 \mathrm{dS} \mathrm{m}^{-1}$, respectively. In relative terms, a reduction of $0.75 \mathrm{~g}$ plant $^{-1}$ was verified among the plants subjected to the ECW of $3.6 \mathrm{dS} \mathrm{m}^{-1}$ compared to the plants subjected to the lowest salt level $\left(0.4 \mathrm{dS} \mathrm{m}^{-1}\right)$. The decrease in the accumulation of dry phytomass of roots in the plants as a function of water salinity occurs as a tolerance mechanism with the purpose of reducing the absorption of toxic ions, especially $\mathrm{Na}^{+}$and $\mathrm{Cl}$, and their consequent carrying to the shoot part, damaging plant growth (Sá et al., 2013). Araújo et al. (2018), when studying phytomass production in the common cashew plant subjected to water salinity ( $\mathrm{ECW}$ varying from 0.3 to $4.3 \mathrm{dS} \mathrm{m}^{-1}$ ), observed that the increase in the ECW negatively affected the dry phytomass of roots in common cashew rootstocks, with a decrease of $9.3 \%$ per unitary increment of the ECW. In a joint evaluation of the LDP, StDP, and RDP data obtained in this research, it is observed that the accumulation of dry phytomass in the cashew stem expressed the higher sensibility of the crop to water salinity.

The dry phytomass of aerial part (Figure 4D) of the cashew plant reduced as the water salinity levels increased, with the reduction of $15.91 \%$ per unitary increment of the ECW. When comparing the DPAP of the plants irrigated with $\mathrm{ECW}$ of $3.6 \mathrm{dS} \mathrm{m}^{-1}$ in relation to those cultivated with water salinity of $0.4 \mathrm{dS} \mathrm{m}^{-1}$, it is possible to verify decreases of $54.37 \%$ ( $2.66 \mathrm{~g} \mathrm{plant}^{-1}$ ). The lowest dry phytomass of the shoot part in the cashew plants obtained in the present study is a result of the lower accumulation of dry phytomass of leaves (Figure 4A) and stem (Figure $4 B$ ) as a function of the stress caused by water salinity. In a study with the 'CCP 76'precocious dwarf cashew, Torres et al. (2014) verified that the irrigation with saline waters (ECW: 0.5 to $12.5 \mathrm{dS} \mathrm{m}^{-1}$ ) resulted in the decrease of the phytomass of the shoot of the plants.

\section{Conclusions}

The water with electrical conductivity above $0.4 \mathrm{dS} \mathrm{m}^{-1}$ results in the decrease of the relative growth in plant height, leaf area, and phytomass accumulation in cashew plants; the cashew clones are sensitive to water salinity from the electrical conductivity of the

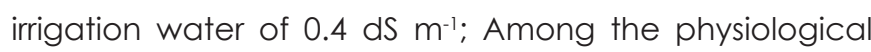
indicators, the leaf area ratio, the sclerophyll index, and the root/shoot ratio of the precocious dwarf cashew are highlighted as salt stress indicators. The use of water with electrical conductivity of $0.4 \mathrm{dS} \mathrm{m}^{-1}$ is recommended for the formation of cashew rootstocks.

\section{References}

Araújo, E.B.G., Sá, F.V.S., Oliveira, F.A., Souto, L.S., Paiva, E.P., Silva, M.K.N., Mesquita, E.F., Brito, M.E.B. 2016.
Crescimento inicial e tolerância de cultivares de meloeiro à salinidade da água. Revista Ambiente \& Água 11: 463471.

Araújo, L.F., Lima, R.E.M., Costa, L.O., Silveira, E.M.C., Bezerra, M.A. 2014. Alocação de íons e crescimento de plantas de cajueiro anão-precoce irrigadas com água salina no campo. Revista Brasileira de Engenharia Agrícola e Ambiental 18: 34-38.

Araújo, S.C.A., Nobre, R.G., Souza, L.P., Almeida, L.L.S., Pinheiro, F.W.A., Elias, J.J. 2018. Produção de portaenxerto de cajueiro irrigado com águas salinizadas e adubação potássica. Revista Brasileira de Agricultura Irrigada 12: 2519-2528.

Benincasa, M.M.P. 2003. Análise de crescimento de plantas, noções básicas. 2.ed. FUNEP, Jaboticabal, Brazil. $41 \mathrm{p}$.

Bezerra, I.L., Nobre, R.G., Gurgel, M.T., Gheyi, H.R., Fernandes, P.D. 2017. Índices fisiológicos e de crescimento de porta-enxertos de cajueiro anão precoce sob estresse salino. Espacios 38: 1-8.

Bezerra, J.D., Pereira, W.E., Silva, J.M., Raposo, R.W.C. 2016. Crescimento de dois genótipos de maracujazeiroamarelo sob condições de salinidade. Revista Ceres 63: 502-508.

Carneiro, P.T., Fernandes, P.D., Gheyi, H.R., Soares, F.A.L. 2002. Germinação e crescimento inicial de genótipos de cajueiro anão-precoce em condições de salinidade. Revista Brasileira de Engenharia Agrícola e Ambiental 6: 199-206.

Costa, P.H.A., Silva, J.V., Bezerra, M.A., Gomes Filho, J.E., Prisco, J.T., Gomes Filho, E. 2003. Crescimento e níveis de solutos orgânicos e inorgânicos em cultivares de Vigna unguiculata submetidos à salinidade. Revista Brasileira de Botânica 26: 289-297.

Donagema, G.K., Campos, D.V.B., Calderano, S.B., Teixeira, W.G., Viana, J.H.M. 2011. Manual de métodos de análise de solo. 2.ed. Embrapa Solos, Rio de Janeiro, Brazil. $230 \mathrm{p}$.

Ferreira, D.F. 2014. Sisvar: a guide for its bootstrap procedures in multiple comparisons. Ciência e Agrotecnologia 38: 109-112.

Freitas, M.A.C., Amorim, A.V., Bezerra, A.M.E., Pereira, M.S., Bessa, M.C., Nogueira Filho, F.P., Lacerda, C.F. 2014. Crescimento e tolerância à salinidade em três espécies medicinais do gênero Plectranthus expostas a diferentes níveis de radiação. Revista Brasileira de Plantas Medicinais 16: 839-849.

Gomes, K.R., Amorim, A.V., Ferreira, F.J., Andrade Filho, F.L., Lacerda, C.F., Gomes-Filho, E. 2011. Respostas de crescimento e fisiologia do milho submetido a estresse salino com diferentes espaçamentos de cultivo. Revista Brasileira de Engenharia Agrícola e Ambiental 15: 365-370.

Gurgel, M.T., Gheyi, H.R., Fernandes, P.D., Santos, F.J.S., Nobre, R.G. 2007. Crescimento inicial de porta-enxertos 
de goiabeira irrigados com águas salinas. Revista Caatinga 20: 24-31.

Isayenkov, S.V., Maathuis, F.J.M. 2019. Plant salinity stress: Many unanswered questions remain. Frontiers in Plant Science 10: 1-11.

Lima, E.S., Silva, E.G., Moita Neto, J.M., Moita, G.C. 2007. Redução de vitamina C em suco de caju (Anacardium occidentale L.) industrializado e cajuína. Química Nova 30: $1143-1146$.

Mesquita, F.O., Cavalcante, L.F., Oliveira Filho, F.X., Rodrigues, R.M., Campos, V.B., Souza, J.K.C. 2019. Neem relative growth under supplementary irrigation with saline waters and biofertilizer. Comunicata Scientiae 10: 45-53.

Nadeem, M., Li, J., Yahya, M., Sher, A., Ma, C., Wang, X., Qiu, L. 2019. Research Progress and perspective on drought stress in legumes: A Review. International Journal of Molecular Sciences 20: 1-32.

Novais, R.F., Neves, J.C.L., Barros, N.F. 1991. Ensaio em ambiente controlado. In: Oliveira, A. J. (ed.) Métodos de pesquisa em fertilidade do solo. Embrapa-SEA, Brasília, Brazil. p.189-253.

Rahneshan, Z., Nasibi, F., Moghadam, A.A. 2018. Effects of salinity stress on some growth, physiological, biochemical parameters and nutrients in two pistachio (Pistacia vera L.) rootstocks. Journal of Plant Interactions 13: 73-82.

Reis, M.V., Figueiredo, J.R.M., Paiva, R., Silva, D.P.C., Faria, C.V.N., Rouhana, L.V. 2016. Salinity in rose production. Ornamental Horticulture 22: 228-234.

Richards, L.A. 1954. Diagnosis and improvement of saline and alkali soils. Department of Agriculture, Washington, USA. 160p.

Sá, F.V.S., Mesquita, E.F., Bertino, A.M.P., Silva, G.A., Costa, J.D. 2013. Biofertilizantes na produção hidropônica de mudas de mamoeiro. Revista Verde de Agroecologia e Desenvolvimento Sustentável 8: 109-116.

Sá, F.V.S., Nobre, R.G., Silva, L.A., Moreira, R.C.L., Paiva, E.P., Oliveira, F.A. 2016. Tolerance of guava rootstocks under salt stress. Revista Brasileira de Engenharia Agrícola e Ambiental 20: 1072-1077.

Santos, D.B., Ferreira, P.A., Oliveira, F.G., Batista, R.O., Costa, A.C., Cano, M.A.O. 2012. Produção e parâmetros fisiológicos do amendoim em função do estresse salino. Idesia 30: 69-74.

Silva Junior, G.S., Morais, M.B., Camara, T.R., Willadino, L. 2012. Crescimento de genótipos diplóides de bananeira submetidos ao estresse salino. Revista Brasileira de Engenharia Agrícola e Ambiental 16: 1145-1151.

Silva, R.N., Lopes, N.F., Duarte, G.L., Moraes, D.M., Pereira, A.L.A. 2007. Análise de crescimento de plantas de Hordeum vulgare L. submetidas a estresse salino. Revista Brasileira de Agrociência 13: 455-463.

Silva, S.M., Oliveira, L.J., Faria, F.P., Reis, E.F., Carneiro, M.A.C., Silva, S.M. 2011. Atividade da enzima nitrato redutase em milho cultivado sob diferentes níveis de adubação nitrogenada e potássica. Ciência Rural 41: 1931-1937.

Sousa, A.B.O., Bezerra, M.A., Farias, F.C. 2010. Desenvolvimento inicial do clone BRS 275 de cajueiro sob irrigação com diferentes níveis salinos. Revista Brasileira de Agricultura Irrigada 4: 166-171.

Sousa, A.E.C., Gheyi, H.R., Correia, K.G., Soares, F.A.L., Nobre, R.G. 2011. Crescimento e consumo hídrico de pinhão manso sob estresse salino e doses de fósforo. Revista Ciência Agronômica 42: 310-318.

Suassuna, J.F., Fernandes, P.D., Nascimento, R., Oliveira, A.C.M., Brito, K.S.A., Melo, A.S. 2012. Produção de fitomassa em genótipos de citros submetidos a estresse hídrico na formação do porta-enxerto. Revista Brasileira de Engenharia Agrícola e Ambiental 16: 1305-1313.

Torres, E.C.M., Freire, J.L.O., Oliveira, J.L., Bandeira, L.B., Melo, D.A., Silva, A.L. 2014. Biometria de mudas de cajueiro anão irrigadas com águas salinas e uso de atenuadores do estresse salino. Nativa 2: 71-78.

Conflict of Interest Statement: The authors declare that the research was conducted in the absence of any commercial or financial relationships that could be construed as a potential conflict of interest.

All the contents of this journal, except where otherwise noted, is licensed under a Creative Commons Attribution License attribuition-type BY. 